Poverty, Agency and Resistance in the Future of International Law: An African Perspective

Obiora Chinedu Okafor

Osgoode Hall Law School of York University, ookafor@osgoode.yorku.ca

Source Publication:

Third World Quarterly. Volume 27, Number 5 (2006), p. 799-814.

Follow this and additional works at: https://digitalcommons.osgoode.yorku.ca/scholarly_works

Part of the African Studies Commons, Comparative and Foreign Law Commons, and the International Law Commons

(c) (i) $\Theta(9$

This work is licensed under a Creative Commons Attribution-Noncommercial-No Derivative Works 4.0 License.

Recommended Citation

Okafor, Obiora Chinedu. "Poverty, Agency and Resistance in the Future of International Law: An African Perspective." Third World Quarterly 27.5 (2006): 799-814.

This Article is brought to you for free and open access by the Faculty Scholarship at Osgoode Digital Commons. It has been accepted for inclusion in Articles \& Book Chapters by an authorized administrator of Osgoode Digital Commons. 


\section{Poverty, Agency and Resistance in the Future of International Law: an African perspective}

\section{OBIORA CHINEDU OKAFOR}

ABSTRACT This article enquires into the likely posture of future international law with respect to African peoples. It does so by focusing on three of the most important issues that have defined, and are likely to continue to define, international law's engagement with Africans. These are: the grinding poverty in which most Africans live, the question of agency in their historical search for dignity, and the extent to which these African peoples can effectively resist externally imposed frameworks and measures that have negative effects on their social, economic and political experience. International law's future posture in these respects is considered through an examination of concrete debates relating to agricultural subsidies, debt usury and relief therefrom, and the relocation of framework socioeconomic governance of almost every African state to external institutions. Insights about what the future holds for the effectiveness of Third World resistance are derived from a consideration of the broad lessons that can be learned from the successes or failures of some past Third World struggles.

The theme of this special issue invites contributors to envision, from varying perspectives, the likely orientation of future international law's engagement with the Third World. ${ }^{1}$ In this article I seek to engage this theme from an African perspective. My analysis is informed as well by the insights generated by critical Third World approaches to international law (TWAIL). ${ }^{2}$ However, without a crystal ball, I can only attempt, as best as I can, to read this normative future from the transcripts of past and current diplomatic dramas and the narratives of historically continuous existential struggles. Difficult as this task is, the historical continuities and discontinuities that meet the 
trained (TWAIL) eye provide an elevated platform from which to gaze into the horizon, and to make out, in outline, a picture of what seems to lie in store for most African peoples in the future of international law.

The three main questions that are dealt with in this article all relate to the extent to which future international law can reasonably be expected to promote much more effectively the well-being of African peoples. The first such question is the extent to which future international law can be reasonably expected to curtail its significant role in the generation and maintenance of conditions of poverty on the African continent. Second, to what extent is this future normative order likely to permit and/or promote the exercise of much more local agency in the governance of African societies? Third, to what extent is this future order likely to allow African peoples the spaces from which they can resist much more effectively the various aspects of our global circumstance that most of them perceive as unfair to them?

Three of the concepts that feature prominently in the questions articulated above require some explanation, or at least a measure of location. These concepts are: poverty, agency and resistance. Let me begin by explaining briefly what I mean by the term poverty. While one of the World Bank's key short hands for measuring poverty-living on less than one dollar a day-is now widely accepted and used as a key measure of that condition around the world, ${ }^{3}$ as I use the term poverty in this article it is meant to include any incidence of the fundamental deprivation, or the serious lack, of basic needs 
(such as food, water, shelter, education, clothing and essential medicines). This understanding of poverty does not of course conflict with the World Bank's overall approach to poverty reduction. ${ }^{4}$ Yet, without enacting what Baxi has called 'a hierarchy of pain and suffering', the understanding of poverty that is suggested here largely avoids the under-inclusion of significant forms of grinding poverty that may not be captured by the day 'dollar-a-day' measure. It also eschews the over-inclusion of some whose suffering pales in comparison with the kind of suffering that is intended to be addressed by the term 'poverty'.

As used in this article, the term agency 'refers not to the intentions people have in doing things but to their capability of doing those things in the first place'. ${ }^{6}$ In articulating this understanding of agency, I am obviously indebted to Anthony Giddens' much-referenced work on 'structuration'.7 Thus, as Seckinelgin has correctly noted, the concept of agency is fruitfully understood as the capability to deal with an issue, question or problem. ${ }^{8}$

For both Richard Falk and Balakrishnan Rajagopal, it is to a combination of state action and social movement protests (not one or the other) that one must turn to understand the meaning of resistance in the international legal order. ${ }^{9}$ It is this approach that has shaped my understanding and use of the term here as encompassing both resistance by African states and social movement action within and across state 
boundaries. That approach has also shaped my conception of the nature of the targets to which such resistance ought to be directed (in appropriate cases) as inclusive, not just of powerful states but also of certain non-state global actors like the key international financial institutions (IFIS) and many transnational corporations (TNCS). My treatment of resistance in this article has also been heavily influenced by Upendra Baxi's seminal work on social movements and human rights, especially the distinctions he draws between 'good' and 'bad' social movements. ${ }^{10}$

The focus in this article on poverty, agency and resistance is justified by the salience and significance of all three concepts in the historical struggles of most African peoples for human dignity. First, it is now almost trite to say that the reduction of poverty on the African continent is key to the success of their overall struggle for dignity. ${ }^{11}$ Yet it bears emphasis here to note that even today ' $40 \%$ of all Africans survive on less than a dollar a day' and far more than that number eke out a living in an atmosphere of grinding material deprivation. ${ }^{12}$ The distributive dimension of this incidence of poverty in most African states is increasingly acknowledged by important decision makers. For example, the Nigerian government's National Economic Empowerment and Development Strategy (NEEDS) clearly states that 'income inequality in Nigeria is very high'. ${ }^{13}$ Similarly, the World Bank has recently shown that widespread and deep inequity in Africa and the rest of the Third World is a key reason for the continued 
prevalence of poverty in those areas of the world. ${ }^{14}$ And the EU is convinced that, 'while several African countries have managed to record impressive economic growth', the 'highly unequal distribution of income [in most African countries] often prevents this growth from having a positive impact on poverty levels'. ${ }^{15}$ Second, the importance of the question of agency in Africa's historical search for dignity is evident in the EU's recent acknowledgement that 'development policies and strategies cannot be imposed from the outside' and that 'the EU should consistently and collectively support Africa and country-owned strategies and policies'. ${ }^{16}$ What is left unsaid by the EU is that, at least for now, this approach to African agency is manifested more at the level of rhetoric and desire, and less at the level of practice. The much-discussed history of the implementation of structural adjustment strategies and other such policies in Africa bears eloquent testimony to the veracity of this claim. ${ }^{17}$ Third, given the prevalence of imposed governance policies in Africa, it is hardly controversial to claim that the capacity of African peoples to resist these impositions and rewrite the relevant global rules will in itself be a highly important factor in the success or failure of each of their struggles for dignity. ${ }^{18}$

The rest of the article is divided into four parts. The first three sections will deal with the questions articulated in the foregoing paragraphs, while the last, concluding, section will provide an overall assessment of future international 
law's likely posture(s) with regard to the need to radically reduce poverty in most African societies, to recognise and promote local agency in almost all these places, and to permit and more meaningfully internalise African resistance to non-favourable global rules.

\section{On poverty}

Any credible consideration of the likely extent of future international law's commitment to the significant reduction of poverty on the African continent must begin from a serious analysis of the existing evidence in this regard. It must therefore proceed from the recognition of the historical reluctance of the international legal order to promote actively the socioeconomic wellbeing of most Africans. As the late Ivan Head once noted:

That international law can, indeed should, contribute to development, is not in question, but it must be remembered that some of the applications of legal principles, designed as they often were in the industrialised countries, are not always in the interest of developing countries. ${ }^{19}$

If, as Ivan Head has shown us, international law has been traditionally insensitive to the cause of poverty reduction (a key objective of development), how likely is it that future international law will become more sensitive in this respect? Will this future normative order be able to contribute more 
effectively to the urgent need to grow real incomes and radically increase access to other socioeconomic benefits on the African continent? In a similar vein will it be able to contribute to the imperative of enthroning far more socioeconomic equity within African states? Two lines of inquiry are suggested by the above questions: the first one relates to future international law's probable relevance or irrelevance to the struggle for increased real incomes and other socioeconomic benefits in Africa. The other concerns that future order's likely attitude to the search for much greater socioeconomic equity within African states. While the investigation of both of these questions is important in order to fully appreciate the likely nature of future international law's relationship to the struggle to reduce poverty on the continent, space does not allow the consideration of both questions here. Thus only the first sub-question will be examined.

That sub-question will be considered by engaging in a relatively general discussion of the question of the possible elimination of the trade-distorting agricultural subsidies that many of the far richer countries of the North have for decades maintained in the global trading system, while ensuring that most African countries effectively open up most of their own markets to imports from these far richer countries. ${ }^{20}$ This is an issue that is governed by the World Trade Organization's (WTO) General Agreement on Tariffs and Trade (GATT) ${ }^{21}$ Given the fact that a sizeable majority of African people live in rural areas and depend for their subsistence on agriculture, ${ }^{22}$ and considering that a 
very large number of African countries are as reliant for their national incomes on the export of their agricultural produce to markets in the geopolitical North, ${ }^{23}$ any factor that negatively affects the volume and prices of these exports to the North poses a highly significant obstacle to the struggle to substantially increase the incomes of African peoples and to thereby reduce the incidence of poverty on the African continent. As such, the relative failure, at least to date, of international (trade) law to deal effectively with these tradedistorting agricultural subsidies has made an important negative contribution to the continuing poverty of far too many Africans. ${ }^{24}$ The extent of this agricultural subsidy has been estimated at $\$ 300$ billion (a massive figure that basically equals the total economic output from all of Africa). ${ }^{25}$ Yet these subsidies have survived in large measure despite the fact that almost all of the farms in the North that benefit from such subsidies are really marginal to the economic output and prosperity of the relevant countries (largely the EU, the USA and Japan). ${ }^{26}$ By contrast, as has been argued above, agriculture remains central to the economic survival of most African peoples.

It is of course important to realise that the maintenance of a national agricultural productive capacity is as sensitive an issue in the First World as it is in Africa. Many Northern countries have expressed the fear that following an anti-subsidy path might lead to the devastation of their agricultural sectors. As such there is a political cost involved for the relevant countries of the North should they support the implementation of international trade 
rules that require the elimination of subsidies. However, apart from the fact that the removal of the relevant subsidies will not necessarily lead to the devastation of every kind of agricultural endeavour in these countries, given the overall scheme of international trade, these countries of the North cannot continue to maintain these kinds of subsidy while ensuring that the far weaker African countries open their own markets and remove subsidies in areas that are as, or even more, sensitive to their economies.

While the Doha Development Agenda (DDA) for 2006 under the aegis of the WTO signals the growing sensitivity of international (trade) law in this important area, ${ }^{27}$ it is hardly clear from any of the discussions on the reduction of these agricultural subsidies that it will, in the near or mediumterm future lead to their total elimination, or to a significant upsurge in the exportation of agricultural produce from the relevant parts of Africa to the countries of the North. What is more, even the partial changes that have been proposed have taken so long to negotiate and congeal, much less to implement, that a measure of pessimism only seems realistic. This less-thanoptimistic reading of international law's likely future posture in this respect is reinforced by the informed realisation that the snail's pace at which the negotiations and implementation of the relevant agreements have so far proceeded essentially reflects, and bows to, the huge South-North power asymmetries of the global order. Had the relevant subsidies been handed out by the much weaker Third World countries, and had the North found itself demanding more market access via the elimination of these subsidies, it is 
highly unlikely that the negotiation and implementation of a remedial agreement would have taken so long. Nevertheless, it is still a commendable development that the negotiations have made some headway at all, however minor or modest its progress thus far.

Thus, as much as these developments indicate the possibility of change in the orientation of future international law's engagement with African peoples, what is most evident from these developments is the law's historical tendency to reflect and respond more effectively to the economic worries and demands of the North, and to be at the same time much less responsive to the socioeconomic challenges facing most African peoples. Since the rapid reduction of the agricultural subsidies discussed above would lead to reasonably increased incomes for a great many African farmers and their states, the likelihood that future international law will contribute much more effectively to the urgent need to grow incomes and increase access to other socioeconomic benefits on the African continent is called into question by the evident reluctance of the much more powerful countries of the North to eliminate these subsidies. While other factors will of course help determine any increases in the real income of African peoples, this allegorical story (about international law's relative insensitivity to the necessity for the elimination of the Northern practice of offering extensive financial subsidies to their farmers, and about the ways in which that behaviour helps maintain the poverty that is rife in many African states) is highly instructive. The continuity of this sort of trend over almost all of modern history and the snail 
speed of current international legal reform in the area does not inspire much confidence in the likelihood that future international law will contribute effectively to the reduction of poverty on the African continent.

As discussed, there is little in reality that suggests that the more powerful states will in the near or medium-term future be willing to make the kinds of fundamental economic concessions to African states in areas such as the elimination of agricultural subsidies without extracting from these African countries certain countervailing concessions (which will tend to detract from the gains of the anticipated cuts in these Northern subsidies). History teaches us that the more economically powerful states, indeed almost all states, hardly ever give up their more powerful positions in a willing fashion. As such, barring any sudden seismic shifts in the configuration of global power, or in the receptiveness of the public and/or ruling elites in the more powerful states of the North to more far-reaching pro-global equity ideas, these more powerful states are likely to continue to act in ways that essentially preserve rather than reform the economic status quo. This is not to say that these states will not make any concessions whatsoever to African states. They will certainly make many such concessions over the near and medium-term future of international law. What one is much less sanguine about is the preparedness and ability of any of these states of the North to make the kind of radical concessions that would fundamentally threaten the privileged socioeconomic positions of almost all of their citizenry vis-a'-vis the vast majority of African peoples. 
On agency

To what extent is future international law likely to permit or promote the exercise of more African agency in the governance of African societies, while restricting to a minimum the current overbearing role of outsiders in the constitution of these societies? If, as Giddens has shown, the term agency is best understood as the capability of doing things, this question can also be framed in terms of the extent to which future international law is likely to permit or promote the capability of African peoples to chart their own futures and to self-constitute. ${ }^{28}$

Here again, a credible inquiry into this question must begin with an attempt to understand the historical tendencies of international law in this connection. Are there historical continuities that meet the eye in this respect? And what kinds of discontinuities, if any, can be observed? As Antony Anghie's work has shown, despite the discontinuities that exist in the exact forms and techniques that were deployed, there is indeed a historical continuity from at least the 16th century onward in international law's tolerance of, if not active support for, the negation and/or erasure of Third World (including of course African) agency. ${ }^{29}$ At root this denial of African agency has taken the form, in each era of global interrelations, of an assault on the capacity of African peoples to govern their own lives and chart their own futures. In the mid-19th to the mid-20th century, this negation of African agency was more formal, extensive and suffocating than it currently is. ${ }^{30}$ This was the era of formal 
European colonial rule over Africa, in which nearly every aspect of the life of almost every African society became marked to some extent by a coercively (and often brutally) superimposed colonial order. ${ }^{31}$ Quite obviously, that specific era of formal colonial rule over Africa has now ended.

However, it is instructive that up to this day the term imposition (or its synonyms) remains the key word when discerning African leaders and scholars describe the African continent's relationship to international institutions or to the North. For example, as Nigerian President Olusegun Obasanjo, a key African leader, has recently noted:

when we [Africans] thought we had regained control of our destiny, and when we believed that we had earned our rights to join the rest of the world as equal partners and discuss mutual co-operation on basis of equitability, we discovered that the position of our continent in the world order had been disadvantageously fixed and predetermined by numerous factors which, for want of a better description, we call colonial legacies. ${ }^{32}$

As remarkably, a diverse group of African scholars such as Michael Chege, George Ayittey and Joe Oloka-Onyango have over the past decade or so expressed similar views about the status of African states and peoples as less than full actors/partners on the global plane, and have bemoaned the entailed denial of African agency to a highly significant degree. While Chege has long dreamed of the day when African societies might 'graduate from 
being passive recipients of charity to full actors in global politics and economics, ${ }^{33}$ Ayittey has more recently chided the World Bank for not taking more steps to 'identify and support the initiative of Africans' ${ }^{34}$ For his own part, Oloka-Onyango is convinced that 'for many [African and other] developing countries IMF prescriptions are in fact edicts giving the latter little choice and almost no room to maneouvre'. ${ }^{35}$ What is more, even the recent EU Strategy for Africa bemoans the tendency for powerful outsiders to negate and over-circumscribe African agency. That document declares quite clearly (and thus commendably) that 'development policies and strategies cannot be imposed [on African societies] from the outside'. ${ }^{36}$

In terms of predicting the orientation of future international law in this respect, at a minimum there is as yet insufficient cause for near or mediumterm optimism. As BS Chimni has shown, if much care is not taken, the ongoing, less formal, less extensive and less suffocating processes via which international law and institutions (usually dominated by the more powerful countries of the North) impose upon, or at least exert strong compliance pressure on, African and other Third World states, risks being transformed into a more formal, more extensive, and more suffocating global regime that is akin in many important respects to the systems of colonial rule that severely constricted African agency in the 19 th and 20 th centuries. ${ }^{37}$ As he has put it: 
been established or repositioned, at the initiative of the first world, and together they constitute a nascent global state whose function is to realize the interests of transnational capital and powerful states in the international system to the disadvantage of third world states and peoples. The evolving global state formation may therefore be described as having an imperial character. ${ }^{38}$

In my own view this assessment of the direction in which the international legal order is moving and is likely to continue to move receives much support from the example of the way in which the framework economic governance of African peoples and of the vast majority of the other Third World countries has been all but seized by certain IFIs, institutions that are clearly and extensively dominated by a small number of the most powerful countries of the North. As I argued not too long ago, it is now clear to most critical observers that the framework governance of African societies has now been effectively relocated to IFIS and certain key countries of the North. ${ }^{39}$ It has, in other words, been externalised. ${ }^{40}$ As economically weak as almost all of them are, African countries which want and need to maintain their creditworthiness-a minimum requirement for participation in the international economy-must come to terms with a largely predetermined set of policies imposed upon them by a loose but cohesive consortium made up of the IMF, World Bank and key G8 countries (and their banks). ${ }^{41}$ In almost all cases, these African countries are required to remove social subsidies, privatise key industries and retrench significant proportions of their public employees. ${ }^{42}$ 
Regardless of one's view about the reasonableness or otherwise of these policies, the point that is being made here is that, despite the usual declarations about these policies being 'home grown', they have in almost every case been imposed by this IMF-led consortium. ${ }^{43}$

This fact of the existence of a figurative noose around the necks of most African policy makers and the denial of African agency in the formulation of broad economic policies for their societies is not negated by evidence of the existence of inevitably minor African input into the constitution of the domestic versions of these policies. The fact that framework economic documents like those outlining the New Economic Partnership for Africa's Development (NEPAD) and the Nigerian NEEDS seem, on the surface, to have been conceived by African leaders themselves, does not at all disprove the argument being made here. For example, upon closer examination, the NEPAD document reflects many of the same neoliberal economic assumptions and tenets that are favoured by the IFIs. As James Gathii has correctly noted, NEPAD adopts the same kinds of market-based development strategies that are highly recommended by the IMF to African countries. ${ }^{44}$ Except for the fact that NEPAD makes a little more provision for the accommodation of some of the anticipated 'losers' in the implementation of the IMF-style economic reforms it endorses, the NEPAD document could easily have been written in an early to mid-1990s, or even in a contemporary, IMF or World Bank office in Washington. ${ }^{45}$ It is no wonder then that the IMF has endorsed 
NEPAD quite effusively. ${ }^{46}$

Similarly, the NEEDS document reproduces every central tenet of the IMF's and World Bank's requirements for certifying a country to its creditors as being engaged in meaningful reform. Indeed, as Sam Amadi has noted, 'a critical reading of the entire [NEEDS] document shows that it still keeps faith with the broad framework of neo-liberal market-oriented reform which the World Bank and the International Monetary Fund strongly endorse'.47 Another reason for concluding that the NEEDS document is largely a product of substantial IFI pressure on the Nigerian government is the precipitate endorsement of NEEDS by the IMF and the World Bank. ${ }^{48}$ What is more, the continued endorsement by the IMF and the World Bank of the NEEDS-driven civil service retrenchment or 'right-sizing', and of the massive fuel price increases that have been implemented in Nigeria, reflects the conformity of this overall economic governance framework with the IMF's and World Bank's own policy prescriptions for Nigeria. ${ }^{49}$ Similarly, while noting some of the difficulties associated with its implementation, the IMF has still described the current government's overall economic reform programme as 'commendable. ${ }^{50}$ It also described the retrenchment of 17000 workers resulting from the implementation of this same economic 'restructuring' agenda as 'progress'.51 All these comments point to the IMF's overall satisfaction with Nigeria's implementation of the same kind of broad economic reform agenda that it has routinely insisted the country adopt. It is 
therefore only reasonable to conclude from this examination of the authorship of both NEPAD and NEEDS that, in most cases, even the presumed African authors of these supposedly 'home grown' documents have, at the very least, been constrained by the pressure exerted over most African states by the key IFIs. It can therefore be reasonably argued that these documents also exemplify the substantial, if partial, erasure of the agency of Africans in their own framework governance. If such key economic policy frameworks have, in essence, been largely formulated by IFIs and the countries of the North that dominate these institutions, thereby effectively removing key decisions from the realm of local decision making, is there still a possibility for engagement in meaningful popular politics at the domestic level? Is it still possible for African peoples to chart their own futures and to self-constitute; at least to the extent that is possible in the more powerful states of the North?

There is little reason, if any, to believe that the answers to these questions will be positive in the near or medium-term future. There is also little reason to suppose that the countries of the North that currently dominate our global order will willingly concede to Africans the level of agency that they desire. Indeed, it would seem that Africans will be lucky to retain even the low levels of agency that they are now allowed under the current international legal order. Thus, unless a critical mass of African societies is able to acquire substantially more global socioeconomic and political power and/or to become better able to resist those aspects of our current and future global circumstance which tend to disadvantage African peoples, the African 
continent of the future will, under the watchful eyes of international law, remain in its historically subordinated global position.

\section{On resistance}

If the resistance of African societies to certain aspects of the international legal order will be central to Africa's escape in the near and medium-term future from the clutches of gross poverty and disadvantage, then the extent to which that future order is likely to be transformed by such resistance matters much. So do the forms that such resistance must take if it is to be effective. As noted in the introduction to this article, the concept of resistance that is deployed here draws on the separate writings of Richard Falk and Balakrishnan Rajagopal. As such, the extant discussion focuses not merely on the dissent expressed by African leaders with respect to the nature of the international legal order, but also on the resistance mounted by African peoples, especially as manifested in the efforts of those social movements that engage in pro-African struggles on the international plane.

An assessment of the extent to which future international law is likely to allow the necessary room for African resistance to its more pernicious aspects can be either more or less optimistic. For instance, at the less optimistic end of the spectrum Joel Ngugi has argued that international law is so problematic for the struggle of African and other Third World peoples that it cannot be reformed from the inside. ${ }^{52}$ To Ngugi the entire episteme that 
grounds international law is so heavily biased in favour of a Eurocentric world-view that it ought to be abandoned by African and other Third World peoples. ${ }^{53}$ In his view third world peoples ought to 'build an alternative oppositional template from which to address the problem of domination in international law'. ${ }^{54}$ However, scholars such as Makau Mutua and BS Chimni are somewhat more optimistic. As critical as he is of the anti-African bias of much of international law, Mutua's work is nevertheless characterised by a certain faith in the possibility, under certain circumstances, of meaningful, even if not entirely satisfactory, reform, however remote this possibility. ${ }^{55}$ For his own part, while not naï ve about the inherent limitations of this approach, Chimni is as convinced of the possibility of internal international legal reconstruction, and even chides Third World scholars for not doing more towards the formulation of alternative international law futures. ${ }^{56}$

Ngugi's relative pessimism about the possibility of fundamental proAfrican reform within the international legal order as it is currently constituted is quite understandable given the historical failure of most Third World attempts at the deep transformation of the global order. For example, the attempt in the 1960s and 1970s by African and other Third World states to promote what they referred to as a 'New International Economic Order' was, for the most part, defeated by the inflexibility on this question of most of the more powerful Northern states. ${ }^{57}$ And, as has already been shown in this 
article, current attempts by a transnational coalition to secure meaningful debt relief and the elimination of trade-distorting agricultural subsidies have also not met with the level of success that African peoples desire.

Yet there is also countervailing evidence of the possibility, under certain conditions, of African and Third World success in pushing through a measure of reform. Even the two African and Third World campaigns for the elimination of agricultural subsidies and in favour of debt relief that are mentioned above have met with some success. Thus not all the attempts by African and other Third World peoples to reform or transform the international legal order can be said to have failed in large measure. For example, it is hard to argue that the struggle to rid the African continent of the scourge of formal and direct colonisation has not met with meaningful, even if not complete, success. ${ }^{58}$ Despite the continuing existence of indirect forms of external control over Africa, few if any existing global regimes equal the direct and suffocating brutality of the formal colonialism that African peoples have now mostly escaped. Second, the epic (African-led) campaign to reform the relevant world trade rules so as to allow Third World peoples far more access to much cheaper essential (especially HIV/AIDS) medications has definitely not failed. ${ }^{59}$ Despite continuing squabbles over the legal character of the Doha Declaration, which records the concessions won by African and other Third World states in this connection, it is now a widely established principle that the relevant global patent protection rules can and ought to be broken in order to provide ready access to cheap life-saving essential drugs to 
the poorer peoples of the world; a large percentage of whom live on the African continent. ${ }^{60}$

In the two examples above the pressure exerted by a coalition of actors that included African leaders, African social movements and/or transnational social movements, was central to the substantial, albeit still limited, success enjoyed in pushing through a pro-African agenda on the global socio-legal stage. In the first case, that is the anti-colonial movement, such pressure was largely exerted by an African mass social movement that included both African leaders and peoples. In the second example, pressure originated from a (sometimes virtual and at times actual) transnational coalition that was composed of African leaders and activists, as well as progressive forces in the North. ${ }^{61}$ As limited as their success has tended to be, almost all of the other modestly fruitful struggles to alter the nature of the contemporary international legal order that have benefited Africans and other Third World peoples have been led or highly supported by coalitions of Third World social movements, progressive Northern forces and Third World and other sympathetic political leaders. ${ }^{62}$ As Rajagopal has correctly noted, from the successful conclusion of the Ottawa Convention on Anti-Personnel Landmines, through the creation of the World Bank Inspection Panels, to the establishment of the World Commission on Dams, concerted Third World and Northern social movement alliances and action have helped drive some notable state-sanctioned changes at the global level. ${ }^{63}$ 
It seems therefore that the efforts of African and other Third World forces at resisting and rewriting aspects of international law that they view with disfavour have met with meaningful success when those struggles have involved a coalition of African and other Third World leaders and proAfrican social movements. ${ }^{64}$ Another key feature of these more successful struggles for greater African dignity at the global level has been the deployment of the added power created when the movement takes on a transnational character. ${ }^{65}$ If these two observations are as correct as I think they are, then they are suggestive of the kinds of strategies that might work in the future for those African peoples who are concerned to resist successfully the aspects of future international law that negatively affect them. Without at all diminishing the continuing relevance of the African state as a global-level vehicle for expressing the dissent of African peoples, it seems that a transnationally focused and social movement-sensitive strategy is imperative if African peoples are more effectively to resist their subordination in the international legal order of the near or medium-term future. ${ }^{66}$ This imperative is reinforced by existing, if cutting-edge, currents in international relations. As Rajagopal has shown, well organised social movements in Africa and the rest of the Third World have at times formed moderately effective alliances with sympathetic Northern forces that have sometimes produced a meaningful measure of desired change in the global order. ${ }^{67}$ Thus, inasmuch as future international law is not likely to allow much 
room for African leaders and peoples to foster fundamental change in the global order of the time, the more effective the strategies deployed by African peoples, the more appreciable the level of transformation that they can initiate. And, as has been argued in this section, the more the strategies of resistance or dissent adopted by Africans resemble the kinds of transnational social movement strategies that seem to have increased their chances of success in the past, the more they will be able to shape the character of future international law.

Despite my recommendation of the use of a combination of both statebased and social movement-style strategies as a way of enhancing the chances of African activism to effect change in the global order, let me end this section by sounding two notes of caution. First of all, I am of course aware that, as Joel Ngugi has argued, as long the resistance launched by Third World peoples has not been viewed as likely to lead to the fundamental reorganisation of the world order, international law has historically been quite happy to 'donate the power of dissent' to African and other Third World peoples while continuing to bequeath to the North the 'prescription of solutions to world problems' ${ }^{68}$ Nevertheless, given the historical experience of African peoples of colonial subjugation in the 18th and 19th centuries and continuing marginally to this day, their very ability to exercise the power of dissent/resistance is in and of itself an act of liberation. What is more, as already pointed out, sufficient evidence already exists to warrant a highly cautious, but nevertheless more optimistic, assessment of the 
contingent possibility of securing certain modest concessions that can markedly improve the lot of a large percentage of Africans in short order. Most African peoples simply do not have the luxury of waiting interminably, it seems, for the day that they can effectively de-couple themselves from the international legal order. And, as I have already argued, the possibility that their resistance will bear some fruit is brightened appreciably when transnationally focused and social movement-sensitive strategies are deployed by African leaders and peoples. This is not to say, of course, that the power of dissent conceded to African peoples by international law is not a significantly limited one. It is acknowledged that on its own the exercise of this power of dissent is unlikely to lead to the fundamental transformation of the world order. Though subject to change, the countervailing power asymmetries are simply too great at present.

Second, I am also aware of, and agree with, Upendra Baxi's cautionary tale regarding the Janus-faced quality of the social movement 'shell'. Like any other shell, this particular kind of shell can of course be filled with either 'good' desire or 'bad' intent. ${ }^{69}$ For instance, as Baxi argues, proponents of hate speech or women's subordination can create and have sometimes created and fostered their own social movements. ${ }^{70}$ These are not movements likely to advantage Third World peoples. As such, wearing a social movement garb, or even taking on a social movement character, will not on its own ensure that a particular reformist or transformative coalition (of the kind recommended here) will promote positions that advantage Third 
World peoples. Having said that, the point being made in this section is that, in order to experience significantly greater success, 'good' Third World international law reform or transformation projects will, it seems, need to work both transnationally and in a social movement mode. The fact that 'bad' social movements can also deploy this strategy should not on its own deter these 'good' movements from adopting this otherwise ethical strategy that significantly increases their chances of success.

\section{Conclusion}

In conclusion, it is useful to provide an overall assessment of the vision of the broad position that most African peoples are likely to occupy in the international legal order of the near and medium-term future presented in this article. This less than clairvoyant reading of that future order's likely overall posture is mediated by the prism of that order's existing historical record with regard to its stance on the radical reduction of poverty in Africa, on the markedly increased promotion of local agency on the continent, and on the African resistance to some of its dictates.

Seen through these prisms, international law is unlikely to undergo any really far-reaching or fundamental transformation. It is unlikely to be transformed in the near or medium-term future into a normative order that serves African people much more effectively. Future international law is unlikely to be altered so as to as foster the kind of much more equitable 
world economic order that is envisaged by the campaigns of African (and other Third World) peoples for the elimination of the agricultural subsidies that key countries in the North provide to many of their farmers. Similarly, future international law is unlikely to function in a way that greatly enhances the self-constitution of African societies. As long as it remains relatively silent about or even tends to promote the denial of African agency in the governance of Africa's own societies, that order will for the most part remain insensitive to the yearnings of African peoples to exercise more control over their own lives than in past and current global orders.

What is more, without more of a focus on deploying the kinds of transnational social movement strategies that have increased their chances of success in the past, African leaders and peoples (like most of their likeminded cohort in the rest of the Third World) are unlikely to improve upon their historically suboptimal record in significantly affecting the play of global politics in ways that will impact much more effectively on the lives of most of the continent's peoples. Yet even the adoption of this kind of innovative strategy is unlikely to win for Africans the kind of fundamental concessions from the far more powerful states of the North that are necessary for Africa and our entire global circumstance to experience speedy and sustainable change. Thus, absent that near or medium-term possibility, and barring any sudden deep structural changes in current ideational, economic, political and social power asymmetries in the global order, change will continue to be administered on Africa (and not really by Africans). And such 
change will continue to drip onto the continent in rather small (but hopefully incremental) doses. 


\section{Notes}

I am grateful to Pius Okoronkwo for his research assistance. Elements of this article are taken from my presentation to the 2005 Annual Meeting of the Canadian Council on International Law entitled, 'Viewing international legal fragmentation from a Third World plane: a TWAIL perspective', and my forthcoming paper entitled 'The precarious place of labour rights and activism in Nigeria's dual economic and political transition (1999-2005)'. The thoughts articulated in this article have been markedly influenced by conversations (actual and virtual) with many of my colleagues in the TWAIL movement, and by the writings and other efforts of Professors Upendra Baxi and Richard Falk. I am most grateful to all of these rare brains for their inspiration and support all these years. Nevertheless, I am solely responsible for any errors or omissions in the article.

1 For a very useful conception of the 'Third World' as constituted by a diverse but nevertheless mostly harmonious 'chorus of voices', see K Mickelson, 'Rhetoric and rage: "Third World" voices in international legal discourse', Wisconsin International Law Journal, 16, 1998, pp $353-419$. I am in complete agreement with this understanding of the expression.

2 For detailed explanations of the nature of TWAIL scholarship, see M Mutua, 'What is TwAIL?', American Society of International Law Proceedings, Washington, DC: American Society of International Law, 2000, p 31; J Gathii, 'Alternative and critical: the contribution of research and scholarship on developing countries to international legal theory', Harvard International Law Journal, 41, 2000, p 263; Mickelson, 'Rhetoric and rage', p 353; and OC Okafor, 'Newness, imperialism, and international legal reform in our time: a TwAIL perspective', Osgoode Hall Law Journal, 43, 2003, p 171.

3 World Bank, Equity and Development, World Bank Development Report 2006, Washington, DC: World Bank, 2005, p 66.

4 Ibid, pp $4-9$.

5 U Baxi, 'Voices of suffering and the future of human rights', Transnational Law and Contemporary Problems, 8, 1998, pp 131-132.

6 A Giddens, The Constitution of Society: An Outline of the Theory of Structuration, Cambridge: Polity Press, 1984, p 9.

7 Ibid.

8 H Seckinelgin, 'A global disease and its governance: HIV/AIDS in sub-Saharan Africa and the agency of NGos', Global Governance, 11, 2005, pp 351-353.

9 R Falk, 'The global promise of social movements: explorations at the edge of time', Alternatives, 12, 1987, p 173; and B Rajagopal, 'International law and social movements: challenges of theorizing resistance', Columbia Journal of Transnational Law, 41, 2003, p 397.

10 Baxi, 'Voices of suffering and the future of human rights', pp 155-156.

11 M Ndulo, 'The democratization process and structural adjustment in Africa', Indiana Journal of Global Legal Studies, 10, 2003, pp 315-317.

12 EU Strategy for Africa: Towards a Euro-African Pact to Accelerate Africa's Development, Communication from the Commission to the Council, the European Parliament and the European Economic and Social Committee, SEC (2005) 1255, Brussels, 12 October 2005, COM (2005) 489 final, pp 5, 31.

13 See Nigeria: National Economic Empowerment and Development Strategy (NEEDS), 2004, at http://www.nigeria.gov.ng/eGovernment/Needs.PDF, p 21; and S Amadi \& F Ogwo (eds), Contextualizing NEEDS: Economic/Political Reform in Nigeria, Lagos: HURILAWS and CPPR, 2004, at http://www.boellnigeria.org/documents/Contextualizing\%20NEEDS.pdf, p 26, accessed 18 February 2005.

14 Equity and Development, p 9.

15 EU Strategy for Africa, p 15.

16 Ibid, p 19.

17 See NJ Udombana, 'How should we then live? Globalization and the New Partnership for Africa's Development', Boston University International Law Journal, 2002, pp 293-313.

18 On the contribution of Third World (including African) resistance to the making of international law, see generally Rajagopal, 'International law and social movements'.

19 See IL Head, 'The contribution of international law to development', Canadian Yearbook of International Law, 1987, 25, pp 29-30.

20 See JJ Steinle, 'The problem child of world trade: reform school for agriculture', Minnesota Journal of Global Trade, 4, 1995, pp 333 - 334. See also R Bhala, 'Challenges of poverty and Islam facing American trade law', Saint John Journal of Legal Commentary, 2003, 18, pp 471 - 473.

21 See the General Agreement on Tariffs and Trade, at http://www.wto.org/english/docs_e/legal_e/ 06gatt_e.htm, accessed 29 November 2005.

22 Our Common Interest: Report of the Commission for Africa ('the Blair Commission Report'), Commission for Africa, 2004, pp 236-237.

23 Ibid, p 236.

24 See also 0 Obasanjo, 'Keynote address to the Governing Council of the International Fund for 
Agricultural Development', 19-20 February 2002, p 3, at http://www.ifad.org/events/gc/25/speech/ obasanjo.htm, accessed 26 September 2005.

25 Ibid, p 4.

26 See Our Common Interest, p 279, section 8.3.1.

27 For the text of the wTo's Doha Development Agenda, see http://www.wto.org/english/tratop_e/dda_e/ dda_e.htm, accessed 26 October 2005. See also G8 Finance Ministers' Conclusions on Development, London, 10 - 11 June 2005, pp 4-5, at http://www.hm-treasury.gov.uk/otherhmtsites/g7/news/ conclusions_on_development_110605.cfm, accessed 26 October 2005; and the Conclusions of the Gleneagles Meeting of the G8 Heads of States, 6 - 8 July 2005, at http://www.g8.gov.uk/ servlet/Front?pagename $1 / 4$ OpenMarket/Xcelerate/ShowPage\&c1/4Page\&cid $1 / 41119518698846, \quad$ accessed 26 October 2005.

28 Giddens, The Constitution of Society.

29 A Anghie, Imperialism, Sovereignty and the Making of International Law, Cambridge: Cambridge University Press, 2004, pp 13-113, 273-309.

30 Ibid, pp $32-113$.

31 Ibid. See also J Gathii, 'Neoliberalism, colonialism and international governance: decentering the international law of governmental legitimacy', Michigan Law Review, 98, 2000, pp 1996- 2024.

32 See 0 Obasanjo, 'Address at the Sixth Edition of the Conference of Montreal', Montreal, 14 May 2000, p 2, at http://nigeriaworld.com/feature/fromasorock/speech/montreal_address_05152000.html, accessed 26 September 2005, emphasis added.

33 See M Chege, 'Remembering Africa', Foreign Affairs, 71, 1991-92, p 146.

34 See GBN Ayittey, 'How the multilateral institutions compounded Africa's economic crisis', Law and Policy in International Business, 30, 1999, pp $585-600$.

35 See J Oloka-Onyango \& D Udagama, 'The realization of economic, social and cultural rights: globalization and its impact on the full enjoyment of human rights', UN Doc. E/CN.4/Sub.2/2000/13, 15 June 2000, paragraph 22.

36 EU Strategy for Africa, p 19.

37 BS Chimni, 'International institutions today: an imperial global state in the making', European Journal of International Law, 15, 2004, p 1.

38 Ibid, pp $1-2$.

39 See OC Okafor, 'Re-conceiving "Third World" legitimate governance struggles in our time: emergent imperatives for rights activism', Buffalo Human Rights Law Review, 6, 2000, p 1.

40 Ibid, $\mathrm{p} 5$.

41 Ibid, pp 6-9.

42 Ibid.

43 Ibid

44 JT Gathii, 'A critical appraisal of the NEPAD agenda in the light of Africa's place in the world trade regime in an era of market centered development', Transnational Law and Contemporary Problems, 13, 2003, pp 179-188. For a more favourable reading of the NEPAD document, see V Mosoti, 'The New Partnership for Africa's Development: institutional and legal challenges of investment promotion', San Diego International Law Journal, 5, 2004, pp 145-147.

45 For example, see the NEPAD document, at http://www.uneca.org/nepad/nepad.pdf, pp 34 - 36, accessed 29 November 2005.

46 Gathii, 'A critical appraisal of the NEPAD agenda', pp 188-191.

47 Ibid, p 12.

48 Ibid, p 19.

49 See IMF, Nigeria: 2005 Article IV Consultation, ImF Country Report No 05/302, 25 March 2005, paras $1,6,13,58$.

50 Ibid, para 58

51 Ibid, para 6.

52 See J Ngugi, 'Making new wine for old wineskins: can the reform of international law emancipate the Third World in the age of globalization', UC Davis Journal of International Law and Policy, 8, 2002, pp 73-80.

53 Ibid, p 76.

54 Ibid, p 79.

55 See M Mutua, 'Why redraw the map of Africa: a moral and legal inquiry', Michigan Journal of International Law, 16, 1995, p 1113.

56 See BS Chimni, 'Third World approaches to international law: a manifesto', in A Anghie et al (eds), The Third World and International Order: Law, Politics and Globalization, Leiden: Martinus Nijhoff, 2003, p 48.

57 Mickelson, 'Rhetoric and rage'. See also TM Franck, 'Lessons of the failure of the NIEo', Canadian Council of International Law Proceedings, Canadian Council on International Law, Ottawa: Canada, 1986, p 82; and OC Okafor, 'The status and effect of the right to development in contemporary international law: towards a South -North entente', African Journal of International and Comparative 
Law, 7, 1995, p 865.

58 S Tharoor, 'The messy afterlife of colonialism', Global Governance, 8, 2002, p 1.

59 See the Doha Declaration on the TRIPS Agreement and Public Health, 14 November 2001, at http:// www.wto.org/english/thewto_e/minist_e/min01_e/mindecl_trips_e.htmhttp://www.wto.org/english/ thewto_e/minist_e/min01_e/mindecl_trips_e.htm, accessed 29 November 2005.

60 JT Gathii, 'The legal status of the Doha Declaration on TRIPS and Public Health under the Vienna Convention on the Law of Treaties', Harvard Journal of Law and Technology, 15, 2002, p 291.

61 See Rajagopal, 'International law and social movements', pp 399-400. See also 'Zoellick faces heat from Congress on scope of TRIPS and health deal', at http://www.cptech.org/ip/wto/p6/insideustrade12062002.html, accessed 29 November 2006; and 'wTo declaration on TRIPS and health-the fight is not over', at http://www.globaltreatmentaccess.org/content/press_releases/01/111301_HGAP_ Doha_decl.html, accessed 29 November 2006.

62 Rajagopal, 'International law and social movements'.

63 Ibid, p 399.

64 Ibid, pp 399-400.

65 Ibid.

66 I had pointed towards the necessity for movement in the direction of transnationally focused Third World struggles for global equity in an earlier article in the Buffalo Human Rights Law Review. See Okafor, 'Re-conceiving "Third World" legitimate governance struggles in our time'.

67 Rajagopal, 'International law and social movements', p 400.

68 Ngugi, 'Making new wine for old wineskins', pp 74-75.

69 Baxi, 'Voices of suffering and the future of human rights', pp 155-156.

70 Ibid. 